\title{
PELATIHAN MANAJEMEN USAHA PADA PELAKU USAHA DODOL KOPI DI DESA SUMBER SARI KECAMATAN KABAWETAN KABUPATEN KEPAHIANG
}

\author{
Ummul Khair $^{1)}$, Elvis Nopriyanti Sherly ${ }^{1)}$, Zufiyardi ${ }^{2}$ \\ ${ }^{1)}$ Program studi Akuntansi, Fakultas Ekonomi, Universitas Muhammadiyah Bengkulu \\ ${ }^{2)}$ Program Studi Pendidikan Ekonomi, Fakultas Keguruan dan Ilmu Pengetahuan, Universitas Muhammadiyah \\ Bengkulu
}

\begin{abstract}
ABSTRAK
Manajemen usaha merupakan salah satu upaya mengatur segala hal dalam menjalankan usaha sehingga dapat mencapai tujuan-tujuan yang diharapkan. Salah satu tujuan tersebut yaitu meningkatkan daya saing pelaku usaha dodol kopi di desa Sumber Sari Kecamatan Kabawetan kabupaten Kepahiang. Manajemen usaha yang dimaksudkan antaranya yaitu manajemen sumber daya manusia, manajemen pemasaran, dan manajemen keuangan. Dodol merupakan salah satu olahan makanan yang berbahan dasar ketan. Keinovatifan produk ini belum diikuti oleh kemajuan pelaku usaha dodol kopi dalam memanajemen usaha tersebut sehingga daya saing produk dodol kopi ini masih rendah.

Kegiatan pengabdian kepada masyarakat ini diikuti oleh 25 orang peserta, yang merupakan pelaku usaha dodol kopi. Kegiatan pengabdian ini dilakukan melalui dua kegiatan yaitu kegiatan penyuluhan dan kegiatan pelatihan manajemen usaha. Kegiatan Pengabdian ini melibatkan mahasiswa sebanyak 5 orang dalam pelaksanaannya.

Hasil kegiatan pengabdian menunjukkan antusisme yang tinggi dari pelaku usaha dodol kopi dalam mengikuti kegiatan ini dan meningkatnya pengetahuan dan keterampilan pelaku usaha dodol kopi yang ditunjukkan dengan peningkatan pemahaman pelaku usaha mengenai manajemen sumber daya manusia sebesar $47 \%$, manajemen keuangan meningkat $26 \%$, serta manajemen pemasaran meningkat $45 \%$.
\end{abstract}

Kata kunci: manajemen keuangan, manajemen pemasaran, manajemen sumber daya manusia, pelaku usaha.

\section{PENDAHULUAN}

Desa sumber sari merupakan salah satu desa yang berada di daerah kaki bukit Gunung kaba atau dikenal dengan daerah kebun teh kabawetan atau wilayah sengkuang karena di daerah ini ada objek wisata air terjun yaitu air terjun sengkuang. Desa Sumber sari merupakan salah satu desa yang berada di kecamatan kabawetan kabupaten kepahiang provinsi Bengkulu. Desa Sumber Sari memiliki jumlah penduduk sebanyak 891 jiwa dengan jumlah KK sebanyak 290. Potensi perkebunan kopi merupakan salah satu potensi yang paling besar dimiliki oleh desa ini, selain dari perkebunan sayuran. Selain itu berdasarkan data yang ada mayoritas penduduk desa sumber sari mata pencariannya adalah petani, hal ini ditunjukkan dari tabel 1 dibawah ini.

\begin{tabular}{|l|c|}
\hline \multicolumn{1}{|c|}{ Profesi } & Persentase \\
\hline Petani/berkebun & $56 \%$ \\
\hline Pedagang & $17 \%$ \\
\hline Buruh kebun teh & $19 \%$ \\
\hline Guru & $5 \%$ \\
\hline Lain-lain & $3 \%$ \\
\hline Total & $100 \%$ \\
\hline
\end{tabular}


Tabel 1 Daftar pekerjaan masyarakat

Berdasarkan data diatas maka dapat dilihat bahwa lebih dari 50\% penduduk sumber sari merupakan petani. Kebun kopi merupakan sumber utama penghasilan penduduknya. Hal ini karena lokasi desa yang tepat yaitu berada di dataran tinggi, sehingga tanaman kopi cukup subur tumbuh disini. Kopi yang dihasilkan rata-rata berjenis robusta.

Di tangan kelompok ibu-ibu PKK desa Sumber Sari kopi yang biasanya dinikmati dengan diseduh sekarang dinikmati dengan cara yang lain yaitu diolah menjadi produk olahan makanan yaitu dodol. Dodol merupakan olahan makanan yang berbahan dasar beras ketan yang dihaluskan dimasak bersama santan dan gula merah.

Berdasarkan survey awal yang dilakukan, Ibu Puji seorang ketua kelompok PKK yang menjalankan usaha olahan dodol kopi ini mengatakan bahwa "kami salah satu kelompok ibu-ibu PKK ingin menyajikan sesuatu yang beda ketika menikmati kopi, karena biasanya kopi hanya dinikmati dengan cara diseduh, jadi kami membuat makanan olahan dodol dengan bahan tambahan kopi karena kopi yang dihasilkan dari desa Sumber Sari ini banyak, selain itu menurut kami dodol kopi ini merupakan produk olahan yang baru karena biasanya dodol yang terkenal adalah dodol buah seperti buah nangka, nanas, salak, pisang, mangga dan pepaya".

Dodol ini diberi nama dodol kopi atau disingkat "dolpi" dengan dua varian rasa yaitu rasa original dan rasa durian. Perbedaan antara keduanya yaitu jika dodol kopi original untuk rasa hanya berbahan dasar kopi, sedangkan dodol kopi durian selain berbahan dasar kopi juga ditambahkan durian sehingga lebih menambah citarasa dodol tersebut. Gambar dibawah ini menunjukkan dua varian rasa dodol kopi yaitu dodol kopi durian dan dodol kopi original.

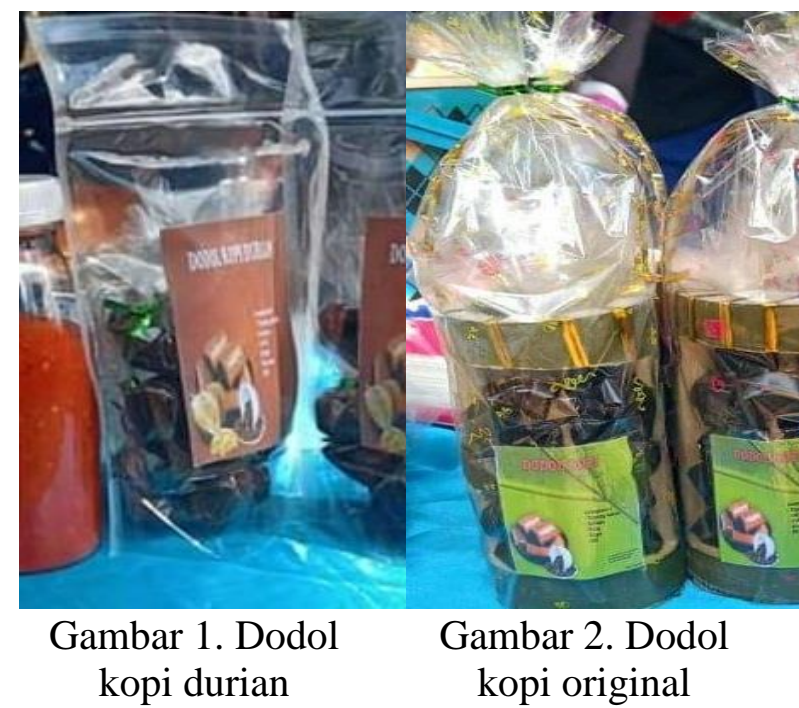

Usaha yang dilakukan oleh ibu-ibu PKK dalam pembuatan dodol ini masih sedikit karena permintaan akan dodol kopi ini belum begitu banyak dan masih dalam lingkungan wilayah Sengkuang saja, selain itu produksinya masih tersendat-sendat karena pelaku usaha dodol kopi ini belum begitu memahami manajemen usaha yang baik sehingga hal itu menyebabkan rendahnya daya saing pelaku usaha dodol kopi ini. Dengan demikian eksistensi dodol kopi masih belum berkembang di pasaran. Efektivitas manajemen usaha berperan sebagai keunggulan bersaing dengan mengembangkan berbagai alat dan strategi untuk membantu organisasi mencapai posisi keunggulan bersaing. Berdasarkan hasil survey awal yang dilakukan maka dapat diketahui bahwa pemahaman pelaku usaha dodol kopi masih rendah. Hal ini dapat dilihat pada tabel dibawah ini:

Tabel 2

Persentase pemahaman manajemen usaha

\begin{tabular}{|c|l|c|c|c|}
\hline $\begin{array}{c}\text { N } \\
\text { o }\end{array}$ & \multicolumn{1}{|c|}{ Keterangan } & $\begin{array}{c}\text { Pah } \\
\text { am }\end{array}$ & $\begin{array}{c}\text { Kurang } \\
\text { paham }\end{array}$ & $\begin{array}{c}\text { Sangat } \\
\text { kurang } \\
\text { paham }\end{array}$ \\
\hline 1 & $\begin{array}{l}\text { Pemahaman } \\
\text { Manajemen } \\
\text { SDM }\end{array}$ & $\begin{array}{c}20 \\
\%\end{array}$ & $45 \%$ & $35 \%$ \\
\hline 2 & $\begin{array}{l}\text { Pemahaman } \\
\text { manajemen } \\
\text { keuangan }\end{array}$ & $\begin{array}{c}45 \\
\%\end{array}$ & $41 \%$ & $14 \%$ \\
\hline 3 & $\begin{array}{l}\text { Pemahaman } \\
\text { manajemen } \\
\text { pemasaran }\end{array}$ & $\begin{array}{c}50 \\
\%\end{array}$ & $37 \%$ & $13 \%$ \\
\hline
\end{tabular}




\section{Ourrat:}

Berdasarkan tabel diatas dapat dilihat bahwa mayoritas pelaku usaha dodol kopi belum memahami manajemen usaha. Hal ini dapat dibuktikan dari persentase atas pemahaman manajemen usaha sebanyak $80 \%$ pelaku usaha dodol kopi belum memahami mengenai manajemen sumber daya manusia, dan sisanya sebanyak $20 \%$ sudah memahami manajemen sumber daya manusia. Sedangkan untuk pemahaman manajemen keuangan $55 \%$ pelaku usaha belum memahami manajemen usaha, sisanya $45 \%$ sudah memahami manajemen keuangan. Dan pemahaman manajemen pemasaran menunjukkan bahwa $50 \%$ pelaku usaha sudah memahami mengenai manajemen pemasaran. Sedangkan sisanya $50 \%$ belum memahami manajemen pemasaran.

Berdasarkan permasalahan di atas, maka dinilai penting untuk menyelenggarakan Pelatihan manajemen usaha pada pelaku usaha dodol kopi di desa sumber sari kecamatan kabawetan kabupaten kepahiang. Kegiatan pengabdian ini terdiri dari dua kegiatan yaitu penyuluhan dan pelatihan manajemen usaha yang mengenai manajemen sumber daya manusia, manajemen pemasaran dan manajemen keuangan pada pelaku usaha dodol kopi di desa Sumber Sari Kecamatan Kabawetan Kabupaten Kepahiang.

Manajemen usaha merupakan kunci keberhasilan usaha. Melalui manajemen usaha yang baik maka akan meningkatkan daya saing usaha dan tentunya akan meningkatkan pendapatan pelaku usaha tersebut. Kurangnya pengetahuan pelaku usaha dodol kopi dalam hal manajemen usaha membuat tim pengabdian kepada masyarakat melakukan beberapa hal yang menyangkut masalah manajemen usaha yaitu melakukan penyuluhan dan pelatihan manajemen usaha produk dodol kopi ini dari sisi manajemen sumber daya manusia, pemasaran dan keuangannya.

Hal yang terkait dengan manajemen usaha yang akan ditawarkan oleh tim pengabdian yaitu dengan memberikan penyuluhan mengenai manajemen sumber daya manusia kepada pelaku usaha dodol kopi, melatih pelaku usaha dodol kopi dalam memanajemen keuangan yaitu mengenai perhitungan harga pokok produksi dan melatih pelaku usaha dodol kopi dalam manajemen pemasaran. (Yusmaniarti Yusmaniarti, 2019)

Pengenalan konsep manajemen usaha berupa perencanaan, pengorganisasian, pengarahan dan pengendalian diharapkan mampu meningkatkan kompetensi pelaku usaha terutama dalam menjalankan usaha baik dari aspek pemasaran, aspek keuangan maupun aspek sumber daya manusia. Pemahaman manajemen usaha penting bagi organisasi sebagai contoh bidang pemasaran, terjadinya resistensi internal dan salah pengertian/pemahaman dari konsep pemasaran dalam suatu organisasi akan mendorong upaya perubahan dalam organisasi pemasaran ${ }^{8}$. Pemasaran berperan tidak hanya sebagai pola pikir dalam organisasi tetapi juga dalam bentuk tindakan sehingga memiliki kontribusi pada pasar dan kinerja keuangan. Dengan demikian pemasaran memiliki hubungan dengan tiga proses bisnis inti dan juga sebagai disiplin ilmu. Peran pemasaran yang berfokus pada pelanggan dalam organisasi menjadi bias dan gagal karena unit atau departemen lain dalam organisasi tidak lagi berfokus pada pelanggan yang disebabkan ketidaksamaan pemahaman konsep pemasaran.

Hasil dari kegiatan penyuluhan dan pelatihan manajemen usaha pada usaha dodol kopi ini yaitu meningkatkan pengetahuan dan keterampilan pelaku usaha dodol kopi sehingga akan meningkatkan daya saing usaha.

\section{METODE KEGIATAN}

Metode pelaksanaan yang dipilih oleh tim pengabdi yaitu berupa penyuluhan dan pelatihan, untuk menambah wawasan pengetahuan dan meningkatkan 
keterampilan pelaku usaha dodol kopi di desa Sumber Sari kecamatan Kabawetan kabupaten Kepahiang. Berdasarkan permasalahan dan solusi yang telah disepakati, maka pelaku usaha dodol kopi diberi penyuluhan dan pelatihan mengenai manajemen usaha yaitu berupa konsepkonsep manajemen baik dari sisi pemasaran, keuangan dan sumber daya manusia.

\section{Penyuluhan}

Penyuluhan yang diberikan kepada pelaku usaha dodol kopi yaitu mengenai beberapa materi terkait dengan manajemen usaha yaitu:

\begin{tabular}{|c|c|}
\hline $\begin{array}{l}\text { Manajemen } \\
\text { sumber daya } \\
\text { manusia }\end{array}$ & $\begin{array}{l}\text { a. Peran tenaga kerja } \\
\text { (anggota kelompok } \\
\text { PKK) } \\
\text { b. Spesialisasi } \\
\text { pembagian tugas } \\
\text { dan tanggungjawab } \\
\text { anggota kelompok } \\
\text { PKK kinerja } \\
\text { c. Evaluasi kelompok } \\
\text { anggota kela } \\
\text { PKK }\end{array}$ \\
\hline $\begin{array}{l}\text { Manajemen } \\
\text { keuangan }\end{array}$ & $\begin{array}{ll}\text { a. } & \text { Konsep biaya } \\
& \text { bahan baku } \\
\text { b. } & \text { Biaya tenaga kerja } \\
& \text { langsung } \\
\text { c. } & \text { Biaya penolong } \\
\text { d. } & \text { Cara menghitung } \\
& \text { harga pokok } \\
& \text { produksi }\end{array}$ \\
\hline $\begin{array}{l}\text { Manajemen } \\
\text { pemasaran }\end{array}$ & $\begin{array}{l}\text { a. Pelabelan } \\
\text { b. Packaging } \\
\text { c. Rencana kegiatan } \\
\text { pemasaran berbasis } \\
\text { online atau offline } \\
\text { d. Layanan kepada } \\
\text { konsumen }\end{array}$ \\
\hline
\end{tabular}

\section{Pelatihan}

Setelah melakukan penyuluhan maka langkah selanjutnya yang dilakukan tim pengabdian yaitu melatih pelaku usaha dodol kopi dalam menghitung harga pokok produksi, dimulai dari mengenali biaya serta formula untuk menghitung harga pokok produksi dodol kopi tersebut.

Pelaksanaan kegiatan pengabdian ini yaitu selama sembilan minggu. Adapun rincian jadwal pengabdian tersebut dapat dilihat pada jadwal dibawah ini :

Jadwal kegiatan

\begin{tabular}{|c|c|c|c|c|c|c|c|c|c|}
\hline \multirow{2}{*}{$\mathrm{N}$} & \multirow{2}{*}{ Nama Kegiatan } & \multicolumn{8}{|c|}{ Bulan ke- } \\
\hline & & 1 & \begin{tabular}{l|l}
2 & 3
\end{tabular} & 4 & 5 & 6 & 7 & & 9 \\
\hline 1 & $\begin{array}{l}\text { Pembuatan } \\
\text { proposal }\end{array}$ & & & & & & & & \\
\hline 2 & $\begin{array}{l}\text { Mengadakan } \\
\text { penyuluhan : } \\
\text { a. Manajemen } \\
\text { sumber } \\
\text { daya } \\
\text { manusia. } \\
\text { b. Manajemen } \\
\text { keuangan } \\
\text { c. Manajemen } \\
\text { pemasaran }\end{array}$ & & & & & & & & \\
\hline 3 & $\begin{array}{l}\text { Mengadakan } \\
\text { pelatihan } \\
\text { Manajemen } \\
\text { keuangan: } \\
\text { Menghitung } \\
\text { harga pokok } \\
\text { produksi }\end{array}$ & & & & & & & & \\
\hline 4 & Pelaporan & & & & & & & & \\
\hline
\end{tabular}

Kegiatan pengabdian ini dilaksanakan di desa Sumber Sari Kecamatan Kabawetan Kabupaten Kepahiang yang berjarak kurang lebih 65 kilometer dari kampus II Universitas Muhammadiyah bengkulu.

\section{HASIL, PEMBAHASAN, DAN DAMPAK}

Kegiatan pelatihan manajemen usaha pada pelaku usaha dodol kopi di desa sumber sari kecamatan kabawetan kabupaten kepahiang diikuti oleh 25 orang peserta. Aktivitas peserta dimulai dengan melakukan registrasi. Sebagaimana jadwal 
yang telah ditetapkan dari jam 08.00-08.30 peserta secara bergiliran melakukan registrasi.

Mulai sesi pertama hingga sesi kedua (terakhir), peserta pelatihan terlihat serius mengikuti setiap materi yang diberikan oleh para pemateri, terlebih pada saat praktik manajemen keuangan yaitu peserta antusias untuk mengikuti pelatihan menghitung harga pokok produksi dodol kopi, selain itu peserta juga tanpa ragu menanyakan setiap kendala yang mereka temukan dalam praktik dan tampak sangat bahagia saat mereka selesai menyelesaikannya praktik manajemen usaha sesuai dengan yang mereka rencanakan.

Pertemuan tatap muka diberikan dengan cara sosialisasi dan pelatihan konsep-konsep manajemen sumber daya manusia, manajemen keuangan, dan manajemen pemasaran. Kegiatan dilanjutkan dengan tanya jawab dari peserta dan tim pelaksana PKM. Pelaksanaan kegiatan dilakukan di kantor desa sumber sari Pelaksanaan kegiatan pengabdian pada masyarakat ini dilakukan oleh tiga orang tim pengabdi dengan pokok bahasan yang disampaikan mengenai:

1. Pemahaman manajemen sumber daya manusia

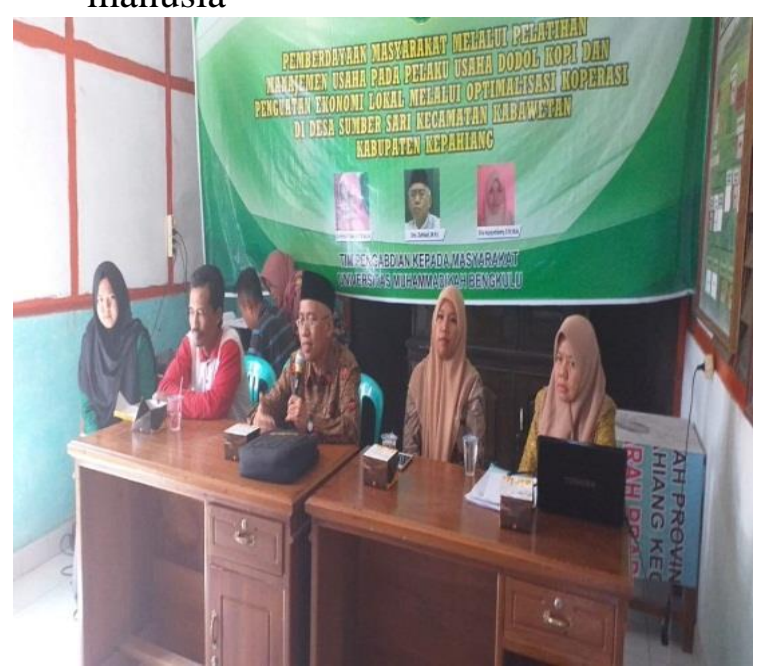

Gambar 4. sosialisasi oleh tim
Pada gambar 4 memperlihatkan bahwa bapak Zufiyardi memberikan materi manajemen sumber daya manusia. Suatu usaha harus memiliki manajemen usaha yang baik untuk menjaga agar suatu produk tetap eksis di pasaran. Salah satu manajemen usaha yang harus dilakukan yaitu manajemen sumber daya manusia. Manajemen sumber daya manusia mencakup bagaimana pelaku usaha dalam memelihara karyawan sehingga karyawan dapat bekerja secara produktif ${ }^{7}$. Tenaga kerja manusia merupakan salah satu unsur terpenting, sehingga suatu kegiatan produksi terjadi. Tanpa tenaga manusia tidak mungkin kegiatan dalam suatu usaha dapat berjalan dengan baik. Interaksi antara manusia dengan faktor produksi lain, seperti mesin, peralatan produksi, bahan baku, tenaga listrik, dan sebagainya yang memungkinkan berjalannya proses produksi. Oleh karena itu, dalam suatu kegiatan produksi selalu terjadi interaksi manusia dengan faktor produksi lainnya.

\section{Pemahaman manajemen pemasaran.}

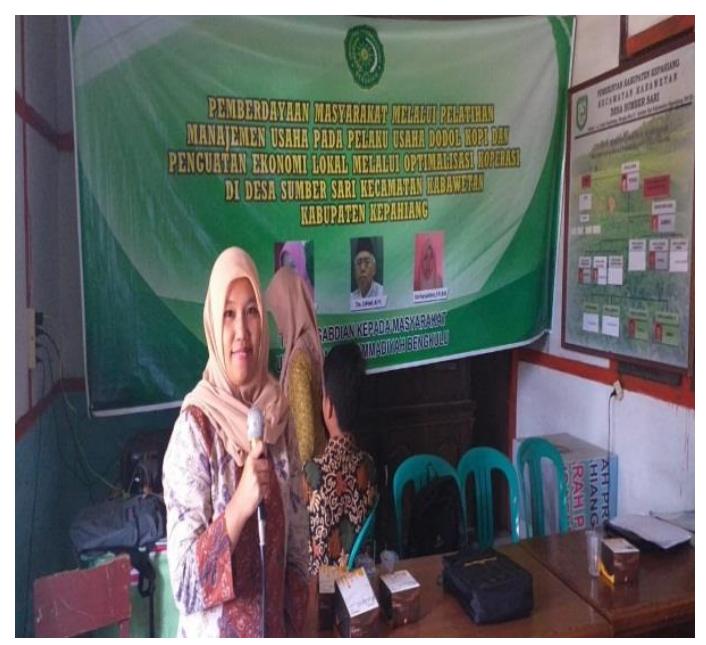

Gambar 5 pemaparan materi oleh tim pengabdi

Gambar 5 diatas memperlihatkan ibu elvis menyampaikan materi mengenai manajemen pemasaran. Pelaku usaha harus benar-benar memahami masalah pemasaran karena pemasaran merupakan ujung tombak keberhasilan suatu usaha. Pemasaran atau 
marketing merupakan salah satu kegiatan yang penting dalam suatu usaha yang menghasilkan produk untuk dijual, dengan tujuan untuk memperoleh keuntungan ${ }^{7}$. Agar daya saing pelaku usaha dodol kopi meningkat maka pelaku usaha dodol kopi perlu melakukan beberapa hal yaitu mulai dari merencanakan, melaksanakan dan mengontrol strategi pemasaran yang dibuatnya agar pelaku usaha dodol kopi dapat memenangkan persaingan atau menguasai daerah pasar tertentu. Selain itu, kepuasan konsumen pun akan tercapai. Dalam pemasaran ada beberapa istilah yang harus dipahami oleh pelaku usaha yaitu, product (barang), promotion (promosi), price (harga), dan place (tempat). Marketing mix merupakan strategi pemasaran yang ditekankan pada empat unsur yang saling menunjang dan berkaitan tersebut.

Adanya produk yang baik yaitu yang memiliki mutu baik, disertai dengan adanya promosi agar dikenal konsumen, lalu dijual dengan harga yang kompetitif dan dapat dikirim konsumen dalam waktu yang tepat, merupakan kegiatan integral dari upaya keberhasilan menjual suatu produk ${ }^{7}$. Salah satu bentuk yang dapat dilakukan oleh pelaku usaha dodol kopi dalam memasarkan produknya selain melalui pemasaran langsung yaitu dengan melalui internet marketing. Internet marketing yang dilakukan oleh pelaku usaha dodol kopi yaitu dapat menggunakan facebook dan instagram. Melalui kedua akun media sosial ini diharapkan lebih tingginya hasil penjualan karena di era digital ini masyarakat sudah memahami media sosial.
3. Pemahaman Manajemen Keuangan

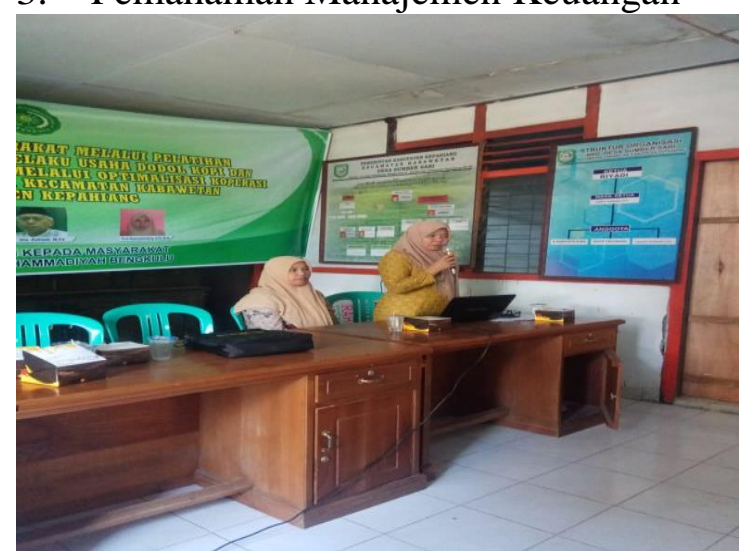

Gambar 6 pemaparan materi oleh tim

Gambar 6 diatas menunjukkan ibu ummul khair memberikan materi pelatihan yaitu manajemen keuangan. Pelaku usaha dituntut untuk bisa menghitung harga pokok produksi pada usahanya karena melalui perhitungan harga pokok produksi dapat diketahui biaya apa saja yang dikeluarkan dan berapa harga jual produk tersebut. Selain itu setiap usaha memerlukan modal,baik menggunakan modal sendiri maupun modal pinjaman.

Modal adalah salah satu faktor produksi yang diperlukan karena modal merupakan faktor produksi untuk pengadaan faktor produksi lain seperti tanah, bahan baku, dan mesin ${ }^{7}$. Dengan mengelola/ mengatur dana/uang dengan baik maka akan mendapatkan keuntungan yang sewajarnya.

Kegiatan dilaksanakan secara bertahap dari pemaparan konsep-konsep yang dilanjutkan dengan pelatihan dan diskusi dari konsep manajemen usaha. Peserta mengikuti kegiatan dengan antusias hal ini ditunjukkan dengan pertanyaanpertanyaan dan tanggapan mengenai materi yang diberikan. Pada gambar 7 dibawah ini dapat dilihat antusis pelaku usaha dodol kopi dalam menerima materi pelatihan. 


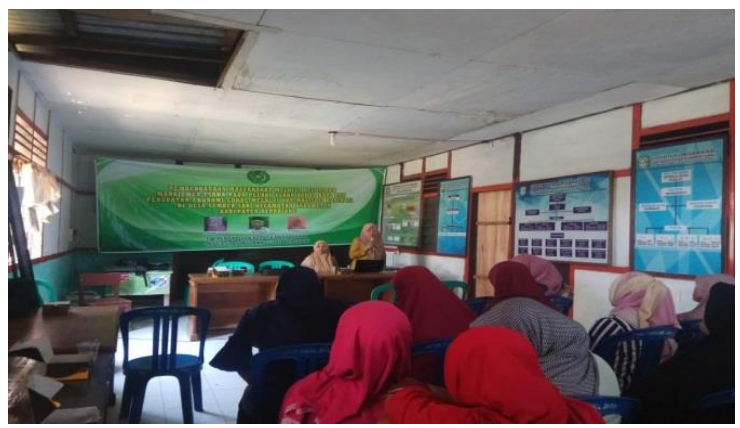

Gambar 7 peserta kegiatan

Selain antusias mendengarkan dan menyimak, masyarakat juga antusias memberikan pertanyaan pada tim pengabdi. Pertanyaan-pertanyaan berkaitan dengan materi dari pengabdi dan permasalahan yang dihadapi peserta saat berada di lapangan.

Secara umum pertanyaan peserta sebagai berikut:

1. Teknik dalam menghadapi pembeli dodol kopi

2. Pengukuran kepuasan pelanggan

Pelatihan manajemen usaha bagi pelaku usaha dodol kopi desa sumber sari dalam program pengabdian masyarakat yang sudah terlaksana ini menunjukkan hasil adanya peningkatan pengetahuan dan keterampilan pelaku usaha dodol kopi. Hal ini dapat dilihat dari tabel dibawah ini:

Tabel 3

Persentase pemahaman manajemen usaha

\begin{tabular}{|c|l|c|c|c|c|}
\hline $\begin{array}{c}\mathbf{N} \\
\mathbf{0}\end{array}$ & Keterangan & $\begin{array}{c}\text { Paha } \\
\mathbf{m}\end{array}$ & $\begin{array}{c}\text { Kurang } \\
\text { paham }\end{array}$ & $\begin{array}{c}\text { Sangat } \\
\text { kurang } \\
\text { paham }\end{array}$ & $\begin{array}{c}\text { Tot } \\
\mathbf{a l}\end{array}$ \\
\hline 1 & $\begin{array}{l}\text { Pemahaman } \\
\text { Manajemen } \\
\text { SDM }\end{array}$ & $67 \%$ & $15 \%$ & $18 \%$ & $\begin{array}{c}100 \\
\%\end{array}$ \\
\hline 2 & $\begin{array}{l}\text { Pemahaman } \\
\text { manajemen } \\
\text { keuangan }\end{array}$ & $71 \%$ & $20 \%$ & $9 \%$ & $\begin{array}{c}100 \\
\%\end{array}$ \\
\hline 3 & $\begin{array}{l}\text { Pemahaman } \\
\text { manajemen } \\
\text { pemasaran }\end{array}$ & $95 \%$ & $5 \%$ & $0 \%$ & 100 \\
$\%$
\end{tabular}

Berdasarkan tabel diatas dapat diketahui bahwa terjadinya peningkatan pemahaman pelaku usaha dodol kopi dalam manajemen usaha. Hal ini dapat dilihat pada manajemen sumber daya manusia terjadi peningkatan dengan peningkatan prosentase pada kategori paham dari $20 \%$ menjadi $67 \%$, artinya pelaku usaha dodol kopi memahami materi yang telah disajikan.

Selanjutnya terjadi peningkatan pemahaman pada manajemen keuangan yang dapat dilihat dari kenaikan jumlah prosentase kriteria paham dari $45 \%$ menjadi $71 \%$, dan yang terakhir terjadi peningkatan juga pada pemahaman pelaku usaha dodol kopi terhadap materi manajemen pemasaran dengan kenaikan prosentase kriteria paham dari $50 \%$ menjadi $90 \%$. Artinya pelaku usaha sudah benar benar memehami materi manajemen usaha.

Penyelenggaraan Pengabdian pada pelaku usaha di desa sumber sari kecamatan kabawetan kabupaten kepahiang pada dasarnya berjalan dengan baik meskipun terdapat sedikit hambatan namun tidak mengurangi semangat pelaku usaha dalam mengikuti kegiatan pelatihan manajemen usaha pada pelaku usaha dodol kopi di desa sumber sari kecamatan kabawetan kabupaten kepahiang. Berikut ini dapat diketahui faktor-faktor pendukung dan faktor-faktor penghambat pengabdian pada masyarakat di Desa sumber sari kecamatan kabawetan kabupaten kepahiang:

\section{Faktor Pendukung}

a. Pelaku usaha dodol kopi di desa sumber sari memiliki keinginan yang kuat untuk meningkatkan pengetahuan mengenai manajemen usaha demi meningkatnya daya saing pelaku usaha.

b. Perangkat desa sumber sari mendukung penuh terhadap kegiatan pelatihan manajemen usaha pada pelaku usaha dodol kopi di desa sumber sari kecamatan kabawetan kabupaten kepahiang.

\section{Faktor Penghambat}

a. Beberapa peserta terlihat belum mengerti dengan manajemen usaha 
b. Beberapa orang peserta pelatihan masih datang terlambat dalam acara pengabdian pada masyarakat ini sehingga mengurangi waktu pelatihan.

Kegiatan pengabdian ini memiliki dampak yaitu meningkatnya pengetahuan dan keterampilan pelaku usaha dodol kopi dalam memanajemen usaha dodol kopi. Hal ini menunjukkan bahwa pelaku usaha dodol kopi menganggap penting penyuluhan dan pengabdian manajemen usaha ini Hal ini dapat dilihat pada tabel 4 dibawah ini:

Tabel 4

Prosentase perubahan pemahaman sebelum dan setelah pengabdian

\begin{tabular}{|c|l|l|l|}
\hline $\begin{array}{c}\text { Aspek } \\
\text { pengetahuan dan } \\
\text { keterampilan }\end{array}$ & \multicolumn{3}{|c|}{ Kenaikan/ penurunan } \\
\hline & Paham & $\begin{array}{l}\text { Kurang } \\
\text { paham }\end{array}$ & $\begin{array}{l}\text { Tidak } \\
\text { paham }\end{array}$ \\
\hline MSDM & $\begin{array}{l}\text { Naik } \\
47 \%\end{array}$ & $\begin{array}{l}\text { Turun } \\
30 \%\end{array}$ & $\begin{array}{l}\text { Turun } \\
17 \%\end{array}$ \\
\hline Man.Keuangan & $\begin{array}{l}\text { Naik } \\
26 \%\end{array}$ & $\begin{array}{l}\text { Turun } \\
21 \%\end{array}$ & Turun 5\% \\
\hline Man.Pemasaran & $\begin{array}{l}\text { Naik } \\
45 \%\end{array}$ & $\begin{array}{l}\text { Turun } \\
32 \%\end{array}$ & $\begin{array}{l}\text { Turun } \\
13 \%\end{array}$ \\
\hline
\end{tabular}

Berdasarkan tabel 4 diatas dapat dilihat dengan jelas bahwa terjadi peningkatan pengetahuan dan keterampilan pemahaman dalam manajemen usaha. Pemahaman manajemen sumber daya manusia terjadi peningkatan pemahaman yaitu sebesar $47 \%$, untuk pemahaman manajemen keuangan terjadi peningkatan sebesar $26 \%$ dari $45 \%$ sebelum pengabdian menjadi $71 \%$. Setelah pengabdian. Sedangkan pemahaman manajemen pemasaran juga meningkat sebesar $45 \%$.

Terjadinya peningkatan pengetahuan pelaku usaha dalam hal manajemen usaha menunjukkan bahwa pelaku usaha bersungguh-sungguh dalam mengikuti kegiatan pengabdian ini. Dengan demikian harapan tim pengabdian yaitu akan diterapkannya pelatihan manajemen usaha oleh pelalu usaha dodol kopi ini.

\section{SIMPULAN}

Program pemberdayaan masyarakat ini melalui pelatihan manajemen usaha bagi pelaku usaha terlaksana dengan baik dan lancar sesuai rencana, dan sebagian besar peserta mampu menerima materi dengan baik. Peserta antusias dengan kegiatan yang ditunjukkan dengan keaktifan peserta dalam proses kegiatan dan adanya peningkatan pengetahuan dan keterampilan pelaku usaha dodol kopi dalam memenjemen usaha yang dibuktikan dari peningkatan prosentase pada pemahaman pelaku usaha terhadap materi manajemen usaha yang diberikan yaitu untuk Manajemen sumber daya manusia meningkat sebesar 47\%, manajemen keuangan meningkat $26 \%$, dan manajemen pemasaran meningkat $45 \%$.

\section{Saran}

Berdasarkan evaluasi dari kegiatan yang sudah dilakukan dapat diberikan saran sebagai berikut:

1. Kegiatan ini dapat dilanjutkan dengan materi lanjutan sesuai antusias dari peserta dengan konsekuensi penambahan waktu pelaksanaan dan biaya yang mengikuti kegiatan.

2. Perlunya kegiatan lanjutan terkait pelatihan sumber daya manusia serta teknik pemasaran produk makanan.

\section{DAFTAR PUSTAKA}

http://Indonesia

investment.com/id/bisnis/komoditas/kopi/ite

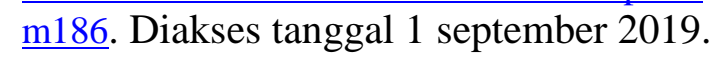
http://majalah .oflencofee.co.id/jenis-jeniskopi-sumatera/ diakses tanggal 3 september 2019

Rahmawati, Fitri. 2013. Materi Pelatihan Pengemasan dan Pelabelan, BPPM DIY, Jogjakarta

Ihwanuddin, Muhammad, et all. 2012. Pengaruh persepsi Atribut Produk terhadap Keputusan Pembelian Rokok 
Merek Gudang Garam Surya Profesional Mild (Studi pada mahasiswa Jurusan Manajemen Angkatan 2011/2012 Fakultas Ekonomi Universitas Negeri Malang) (online). Diakses tanggal 3 September 2019

Malayu, SP, Hasibuan. 2007.Manajemen, Dasar, Pengertian, dan masalah. Jakarta: Bumi Aksara

Tjiptono, Fandy. 2008. Strategi Pemasaran. Yogyakarta: CV Andi Offset

prawirosentono, Suyadi. 2007. Pengantar bisnis modern. Jakarta: Bumi Aksara

Kotler, P \& Amstrong, G. (2012). Priciple of Marketing. 14Edition, New Jersey : Prentice Hall International, Inc.

Yusmaniarti Yusmaniarti, M. M. (2019). Pemberdayaan Pengurus Gapoktan Teratai Untuk Meningkatkan Tatakelola Administrasi Simpan Pinjam Bagi Masyarakat Di Desa .... Jurnal Pengabdian Masyarakat Bumi Raflesia, 2(2), 193-200. 